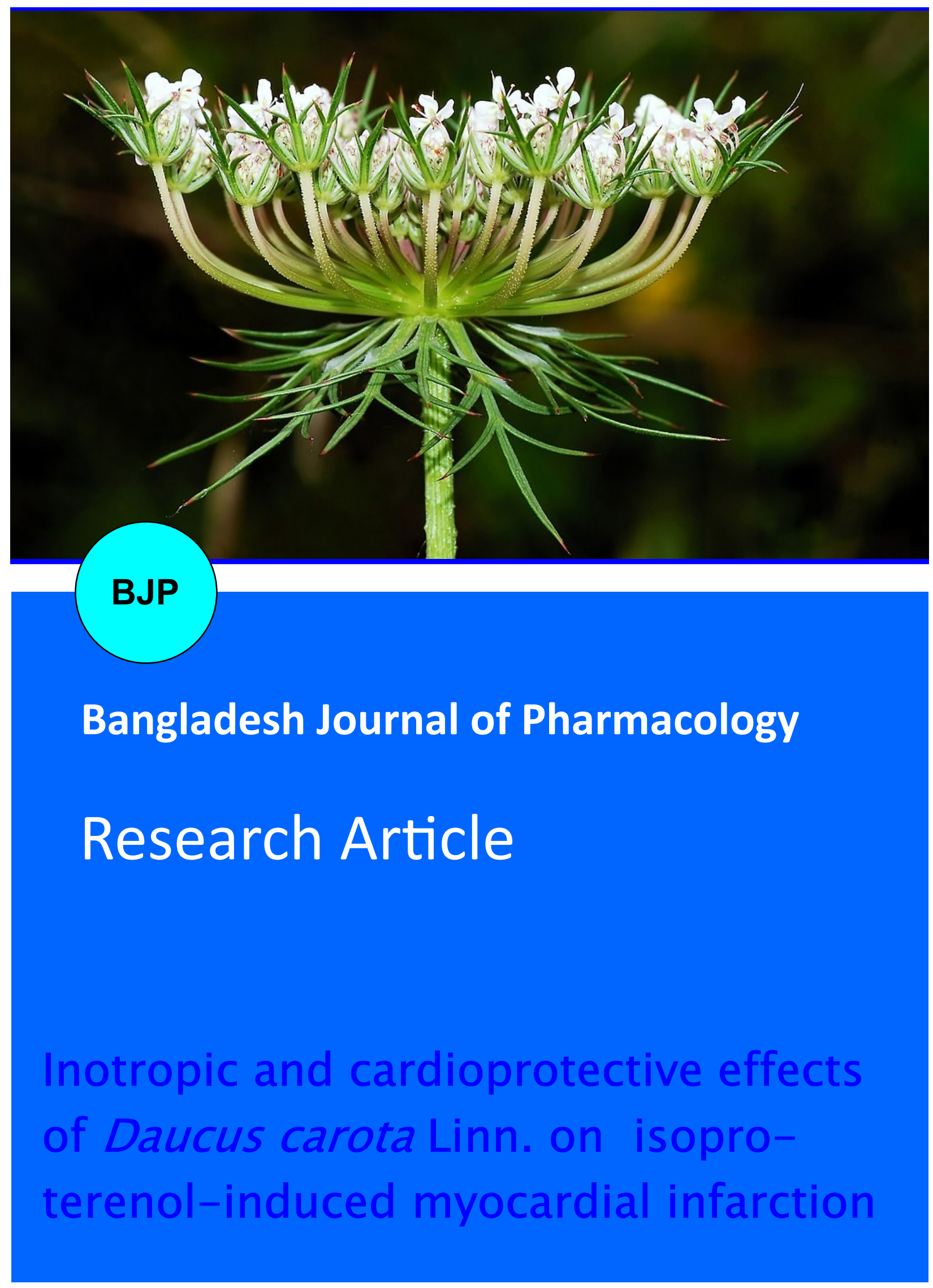




\section{Inotropic and cardioprotective effects of Daucus carota Linn. on isoproterenol-induced myocardial infarction}

\section{P. Muralidharan'1, G. Balamurugan' ${ }^{1}$ and Pavan Kumar'2}

${ }^{1}$ Department of Pharmacology and Toxicology, C. L. Baid Metha College of Pharmacy, Jyothi Nagar, Thoraipakkam, Chennai 97, Tamil Nadu; ' ${ }^{2}$ epartment of Toxicology, Hi-tech City, Madhapur, Andhrapradesh 500081, India.

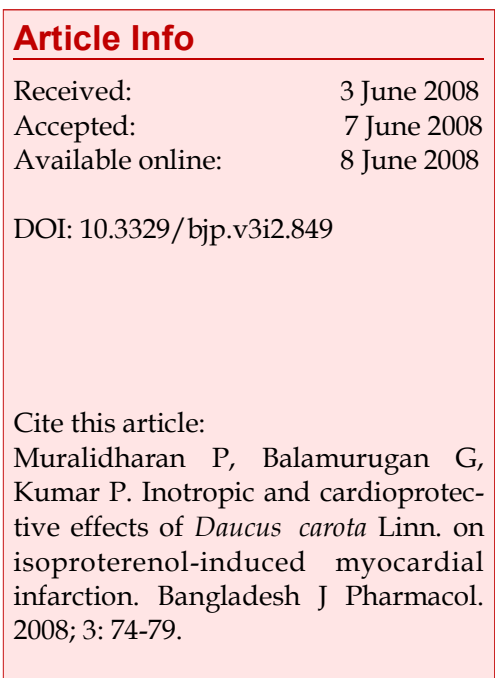

\begin{abstract}
Daucus carota Linn. tubers were extracted with water and analyzed for its inotropic and cardioprotective effects by measuring various biochemical parameters at the test doses of 250 and $500 \mathrm{mg} / \mathrm{kg}$. Isoproterenol $(5.3 \mathrm{mg} / \mathrm{kg}$ and $8.5 \mathrm{mg} / \mathrm{kg}$ ) was administered subcutaneously on $29^{\text {th }}$ and $30^{\text {th }}$ day respectively in order to induce myocardial infarction. Cardiac tonicity was estimated by evaluating $\mathrm{Na}^{+} \mathrm{K}^{+}$ATPase, $\mathrm{Mg}^{2+}$ ATPase and $\mathrm{Ca}^{2+}$ ATPase levels in heart. The levels of $\mathrm{Na}^{+} \mathrm{K}^{+} \mathrm{ATPase}$ and $\mathrm{Mg}^{2+} \mathrm{ATPase}$ were decreased and that of $\mathrm{Ca}^{2+}$ ATPase was increased in extract-treated group significantly $(p<0.001)$. Cardioprotection was assessed by estimating serum aspartate transaminase, alanine transaminase, lipid peroxidase, and lactate dehydrogenase levels and cardiac total protein and lipid peroxidase, and lactate dehydrogenase. The levels altered by isoproterenol were restored significantly by the administration of the extract. The result of the study implies that $D$. carota is a potential source to protect heart from myocardial infarction and to maintain its tonicity.
\end{abstract}

\section{Introduction}

Daucus carota Linn. (Family: Umbeliferae) is an annual or biennial herb, whose roots are eaten raw and also cooked in many parts of the world. It is cultivated extensively through out the world including India. The root of the plant is used as a diuretic and inotropic (Chaterjee and Prakesh, 1995). The volatile oil from the seeds are reported to possess analgesic and antiinflammatory activity (Prochezhian and Ansari, 2000). The roots are reported to possess hepatoprotective property (Bishayee et al., 1995). Extensive phytochemical investigations carried out on D. carota revealed the presence of many chemical constituents including flavanoids and glycosides such as apigenin- 4 -o- $\beta$-glucoside and apigenin-7-o- $\beta$ galactopyranosyl- $\beta$ D-mannopyronoside (Kritikar and Basu, 1981), which are considered significant for inotropic property. All these factors and lack of scientific data on the cardiac activities led to the investigation of the inotropic and cardioprotective potential of $D$. carota aqueous extract in rat models.

\section{Materials and Methods}

\section{Plant material}

Fresh tuberous roots of $D$. carota were purchased from a vegetable market during September 2006 (Chennai, 
Tamil Nadu, India). The identity of the species was confirmed by Dr. P. Jayaraman, Director, Plant Anatomy Research Centre, Chennai. A voucher specimen was deposited at the Department of Pharmacology, C. L. Baid Metha College of Pharmacy, Chennai, India.

\section{Preparation of extract}

Fresh tuberous roots of $D$. carota were washed with running water and cut into small pieces. It was dried under shade and $500 \mathrm{~g}$ of the dried root pieces were made into a coarse powder. The powder was passed through a 20 mesh sieve and extracted with distilled water for 24 hours by cold maceration at room temperature (Chopra et al., 1992). The extract was filtered and concentrated with the help of rotary vacuum evaporator. The percentage yield was calculated as $16.5 \%$ with respect to the dried material. The extract obtained was suspended in $1 \%$ sodium carboxy -methyl cellulose for animal administration.

\section{Experimental animals}

In bred adult Wistar rats (150-200 g) of either sex obtained from animal house of C. L. Baid Metha College of Pharmacy were used for the study. They were maintained in a well ventilated room with 12:12 hours light:dark cycle in poly propylene cages and fed with standard pellet diet (Hindustan Lever Ltd, Mumbai) and water ad libitum. All the animals were acclimatized to the laboratory conditions one week prior to the ini-tiation of the study.

\section{Acute toxicity studies}

Rats selected by random sampling technique were used in the study. Acute oral toxicity was performed as per OECD-423 guidelines (Ecobichon, 1997). The animals were fasted overnight, provided only water after which EMC was administered to the groups orally at the dose level of $5 \mathrm{mg} / \mathrm{kg}$ body weight by gastric intubation and the groups were observed for 14 days. If mortality was observed in 2 or 3 animals, then the dose administered was assigned as a toxic dose. If mortality was observed in one animal, then the same dose was repeated again to confirm the toxic dose. If mortality was not observed, the procedure was repeated for further higher doses such as 50, 300 and $2,000 \mathrm{mg} / \mathrm{kg}$ body weight. The animals were observed for toxic symptoms such as behavioral changes, locomotion, convulsions and mortality for 72 hours.

\section{Inotropic effect}

The animals were divided into 3 groups each comprising of 6 animals. Group I served as a control group receiving $1 \%$ sodium carboxymethyl cellulose (1 $\mathrm{mL} / 100 \mathrm{~g})$. Group II and III animals received aqueous extract of D. carota at a dose of 250 and $500 \mathrm{mg} / \mathrm{kg}$ suspended in $1 \%$ sodium carboxymethyl cellulose respectively for 7 days. On day 8 , the animals were sacrificed by cervical dislocation and the heart was dissected out, washed with ice-cold physiological saline and $100 \mathrm{mg}$ of it was weighed and homogenized in chilled $0.1 \mathrm{M}$ tris hydrochloric acid in potterelvehjem teflon homogenizer. The homogenized samples were analyzed for enzymes such as $\mathrm{Na}^{+} \mathrm{K}^{+}$ATPase (Bonting, 1970), $\mathrm{Ca}^{2+}$ ATPase (Hjerten and Pan, 1983) and $\mathrm{Mg}^{2+}$ ATPase (Ohinishi et al., 1982).

\section{Cardioprotective activity}

The animals were divided into 4 groups of 6 animals each. Group I animals served as vehicle control receiving $1 \%$ sodium carboxymethyl cellulose (1 mL/100 g body weight) for 28 days. Group II animals were standard diet and water ad libitum for initial 28 days and administered isoproterenol $(5.25 \mathrm{mg} / \mathrm{kg}$ and $8.5 \mathrm{mg} / \mathrm{kg}$ ) subcutaneously on $29^{\text {th }}$ and $30^{\text {th }}$ day respectively (Rona et al., 1956). Group III and IV animals received the extract at a dose of 250 and 500 $\mathrm{mg} / \mathrm{kg}$ respectively for 28 days and administered isoproternol $(5.23 \mathrm{mg} / \mathrm{kg}$ and $8.5 \mathrm{mg} / \mathrm{kg}$ ) subcutaneously on $2^{\text {th }}$ and $30^{\text {th }}$ day respectively. After 30 days of experimental period the animals of all groups were anesthetized with phenobarbital sodium (35 mg/kg) intraperitoneally and blood was drawn from external jugular vein of the rat. Serum was separated by centrifugation for the estimation of serum aspartate transaminase (Reitman and Frankel, 1957), serum alanine transaminase (Mohur and Cooke, 1979), serum lipid peroxidase (Okhawa and Onishi, 1979) and serum lactate dehydrogenase (Alam, 2002). The animals were then sacrificed by cervical dislocation and the heart was dissected out, washed with ice-cold physiological saline and $100 \mathrm{mg}$ of it was weighed and homogenized in chilled $0.1 \mathrm{M}$ tris hydrochloric acid buffer $(5 \mathrm{~mL} ; \mathrm{pH}$ 
7.4) at $4^{\circ} \mathrm{C}$. The homogenate was centrifuged and the supernatant liquid was used for the estimation of total protein (Lowry et al., 1951), lactate dehydrogenase (Nieland, 1955) and lipid peroxidase (Okhawa and Onishi, 1979).

\section{Results}

There was a significant decrease in membrane $\mathrm{Na}^{+} \mathrm{K}^{+}$ATPase and $\mathrm{Mg}^{2+}$ ATPase and significant increase in membrane $\mathrm{Ca}^{2+}$ ATPase in animals treated with aqueous extracts of Daucus carota extract $(p<0.01)$ when compared to control group in a dose dependent manner (Table I). Serum aspartate transaminase and alanine transaminase levels were significantly increased $(p<0.001)$ in isoproterenol challenged group, when compared to control groups. Extract at the dose of $250 \mathrm{mg} / \mathrm{kg}$ and $500 \mathrm{mg} / \mathrm{kg}$ showed a significant decrease in the enzyme levels $(p<0.01$ and $p<0.001)$, when compared to isoproterenol-treated group. Lipid peroxidase in serum was significantly increased $(p<0.001)$ in isoproterenol-induced groups. Treatment with at $250 \mathrm{mg} / \mathrm{kg}$ and $500 \mathrm{mg} / \mathrm{kg}$ doses showed significant decrease $(\mathrm{p}<0.01)$ in lipid peroxidase level, when compared to isoproterenol-treated group. Lactate dehydrogenase levels of serum significantly increased $(p<0.001)$ in isoproterenol challenged group, whereas extract at the dose of $250 \mathrm{mg} / \mathrm{kg}, 500 \mathrm{mg} / \mathrm{kg}$ showed a significant decrease in the enzyme levels $(p<0.01$ and $p<0.001)$ (Table II). Significant $(p<0.001)$ decrease in the total protein was observed in isoproterenol treated group, when compared to control group. Treatment with extract $(500 \mathrm{mg} / \mathrm{kg})$ brought the total protein level to near normal level $(p<0.001)$ in heart homogenate. The extract-treated group at 250 $\mathrm{mg} / \mathrm{kg}$ dose showed increased $(\mathrm{p}<0.01)$ protein level when compared to isoproterenol challenged rats. Lipid peroxidation in heart homogenate was significantly increased $(p<0.001)$ in isoproterenol-induced groups. Treatment with at 250 and $500 \mathrm{mg} / \mathrm{kg}$ dose showed significant decrease $(\mathrm{p}<0.01$ and $\mathrm{p}<0.001)$ in lipid peroxidase level, when compared to isoproterenoltreated group. Lactate dehydrogenase in heart homogenate was significantly decreased $(p<0.001)$ in isoproterenol-induced group whereas treatment with 250 and $500 \mathrm{mg} / \mathrm{kg}$ dose of the extract showed significant increase $(\mathrm{p}<0.001)$ in lactate dehydrogenase level, when compared to isoproterenol-treated group.

\section{Discussion}

Cardiac glycosides and catecholamine have been used as the main therapeutic drugs in the treatment of congestive heart failure (Kitada et al., 1987); however the dangers of cardiac glycoside intoxication are well documented and doubts have been expressed about their long-term effectiveness. The use of catecholamine is limited by their insufficient differentiation between the positive ionotropic and chronotropic actions, their potential arrythmogenic properties and tachyphylaxis is due to receptor down regulation (Beller et al., 1971). The cardiac enzyme profile indicates that extract of Daucus carota exhibited inotropic like activity which manifested as a result of general decrease in the activity of $\mathrm{Na}^{+} \mathrm{K}^{+} \mathrm{ATPase}$ and $\mathrm{Mg}^{2+} \mathrm{ATPase}$ and an increase in $\mathrm{Ca}^{2+}$ ATPase. This inhibition of $\mathrm{Na}^{+} \mathrm{K}^{+}$ATPase is similar to action of cardiac glycosides (Akera and Brody, 1997). Cardiac glycosides are specific and unique inhibitors of $\mathrm{Na}^{+} \mathrm{K}^{+}$ATPase at normal concentrations. $\mathrm{Na}^{+} \mathrm{K}^{+}$ATPase inhibition by cardiac glycosides leads ultimately to increase in intracellular $\mathrm{Ca}^{2+}$ concentration through $\mathrm{Na}^{+} / \mathrm{Ca}^{2+}$ exchanger and an associated increase in slow inward $\mathrm{Ca}^{2+}$ currents as well as in transient $\mathrm{Ca}^{2+}$ currents (Goto

\section{Table I}

\begin{tabular}{|lccc|}
\hline \multicolumn{2}{|c|}{ Effect of Daucus carota extract on clinical marker enzymes } \\
\hline & $\mathrm{Na}^{+} \mathrm{K}^{+}$ATPase & Ca $^{2+}$ ATPase & Ca $^{2+}$ ATPase $^{-}$ \\
\hline Control & $0.870 \pm 0.048$ & $0.420 \pm 0.029$ & $0.765 \pm 0.049$ \\
Extract $(250 \mathrm{mg} / \mathrm{kg})$ & $0.730 \pm 0.073^{\mathrm{a}}$ & $0.680 \pm 0.042^{\mathrm{a}}$ & $0.641 \pm 0.042^{\mathrm{a}}$ \\
Extract $(500 \mathrm{mg} / \mathrm{kg})$ & $0.670 \pm 0.087^{\mathrm{a}}$ & $0.716 \pm 0.047^{\mathrm{a}}$ & $0.582 \pm 0.034^{\mathrm{a}}$ \\
Values are Mean $\pm \mathrm{SD} . \mathrm{n}=6$, a $<<0.01$ & & & \\
\hline
\end{tabular}


Table II

Effects of Daucus carota extract on serum and cardiac enzymes and total protein levels

\begin{tabular}{|c|c|c|c|c|}
\hline & Control & Isoproterenol & $\begin{array}{l}\text { Extract }(250 \mathrm{mg} / \mathrm{kg}) \\
\text { plus isoproterenol }\end{array}$ & $\begin{array}{c}\text { Extract }(500 \mathrm{mg} / \mathrm{kg}) \\
\text { plus isoproterenol }\end{array}$ \\
\hline \multicolumn{5}{|l|}{ Serum enzymes } \\
\hline Aspartate transaminase (IU/L) & $19.08 \pm 0.97$ & $36.77 \pm 0.73 b$ & $34.79 \pm 0.89 a$ & $32.22 \pm 0.73 a$ \\
\hline Alanine transainase (IU/L) & $26.83 \pm 1.01$ & $44.83 \pm 1.23^{b}$ & $43.31 \pm 0.88^{a}$ & $38.22 \pm 0.84^{b}$ \\
\hline $\begin{array}{l}\text { Lipid peroxidase } \\
\text { (nmols of TBARS/mg of protein) }\end{array}$ & $3.47 \pm 0.17$ & $5.60 \pm 0.28 \mathrm{~b}$ & $4.94 \pm 0.41^{a}$ & $4.06 \pm 0.52^{a}$ \\
\hline Lactate dehydrogenase (IU/L) & $4.39 \pm 0.58$ & $7.31 \pm 0.87 \mathrm{~b}$ & $6.29 \pm 0.61^{a}$ & $5.55 \pm 0.52^{b}$ \\
\hline \multicolumn{5}{|l|}{ Cardiac total protein and enzymes } \\
\hline Total protein (mg/g tissue) & $109.3 \pm 2.95$ & $81.84 \pm 1.64^{\mathrm{b}}$ & $85.05 \pm 1.32^{a}$ & $90.31 \pm 2.96^{\mathrm{b}}$ \\
\hline $\begin{array}{l}\text { Lipid peroxidase } \\
\text { (nmols of TBARS/mg of protein) }\end{array}$ & $6.60 \pm 0.52$ & $9.02 \pm 1.31^{b}$ & $7.90 \pm 0.94 \mathrm{a}$ & $6.99 \pm 1.16^{b}$ \\
\hline Lactate dehydrogenase (IU/L) & $138.52 \pm 2.02$ & $114.22 \pm 2.13^{b}$ & $120.07 \pm 2.92^{b}$ & $124.70 \pm 2.73^{b}$ \\
\hline
\end{tabular}

et al., 1992).

The present investigation reveals the cardio-protective effect of the extract, a neutraceutical on isoproterenolinduced myocardial infractions in rats. Myocardium contains an abundant concentration of diagnostic marker enzymes of myocardial infractions like lactate dehydrogenase and transaminases and once metabolically damaged, releases its content into the extracellular fluid (Suchalata and ShyamalaDevi, 2004). In isoproterenol-induced myocardial infarcted rats, the increased activity of serum marker enzymes accompanied by their concomitant reduction in the heart homogenate confirm the onset of myocardial necrosis. Hence the total concentration of the marker enzymes were found to be decreased in the heart tissue of isoproterenol infarcted rats when compared with the control, which may be the reflection of consequences of cellular injury due to lipid peroxides. Isoproterenol is well known to generate free radicals and to stimulate lipid peroxidation, which will be a causative factor for irreversible damage to the myocardium (Senthil Kumar et al., 2001).

The increased levels of thiobarbituric acid reactive substances indicate the excessive formation of free radicals and activation of lipid peroxidation system resulting in irreversible damage to the heart in animals subjected to isoproterenol stress. The significant increase observed in the levels of lipid peroxidase in serum and heart of isoproterenol infarcted rats is compared with control. Following treatment with extract, serum marker enzymes of rats were found to be significantly decreased whereas the heart tissue marker enzyme showed significant increased level when compared to isoproterenol-induced myocardial infarcted rats and this could be due to the antioxidant and free radical scavenging property of the extract. Epidemiological studies on dietary intake of carotenoids have been implicated to be helpful in the decreased risk of cardiovascular disease (Knekt et al., 1994). In a study with six prospective dietary carotenoids and coronary heart disease cases, four measured provitamin A carotenoid consumption, one the consumption of fruits and vegetables high in carotenoids and one the total of five carotenoids ( $\alpha$ and $\beta$-carotene, lutein, lycopene and cryptoxanthin). The animal which consumed all the five carotenoids was found with relatively low risk of events of coronaryheart diseases (Allard et al., 1994). In the extract pretreated group, rats showed a significant decrease in lipid peroxides level both in serum and heart tissue when compared with isoproterenol myocardial infarcted rats. Previous investigations have shown that beta carotene is a major carotenoid precursor of vitamin A which can efficiently quench singlet oxygen and function as anti-oxidant (Burton 
and Ingold, 1994).

The therapeutic efficacy of the extract may be due to its anti-oxidant, anti-lipid peroxidative, free radical scavenging and inotropic property that could have prevented isoproterenol-induced tissue injury. Thus it could be concluded that the extract protects experimental myocardial infraction in rats. Further studies have to be performed on inotropic activity in isolated guinea pig atrial preparations, which is expected to reveal the exact mechanism of the extracts.

\section{Ethical Issue}

The study was approved by the Institutional Animal Ethical Committee (Ref No: IAEC 12/15 - CLBMCP, dated 17-082006).

\section{References}

Akera T, Brody TM. The role of $\mathrm{Na}^{+} \mathrm{K}^{+}$ATPase in the ionotropic actions of digitalis. Pharmacol Rev. 1997; 29: 187 -220 .

Alam H. Varley Practical clinical biochemistry. $6^{\text {th }}$ ed. Gove luck, 2002, pp 522-23.

Allard JP, Royall D, Kurian R, Muggli R, Jeejeebhoy K. Effects of carotene supplementation on lipid peroxidation in humans. Am J Clin Nutr. 1994; 59: 588-90.

Beller GA, Smiy TW, Abelmann WH, Haber E. Digitalis intoxication, a prospective clinical study with serum level correlations. New Engl J Med. 1971; 284: 989-97.

Bishayee A, Sarkar A, Chaterjee M. Hepatoprotective activity of carrot against carbon tetrachloride intoxication in mouse liver. J Ethanopharmacol. 1995; 47: 69-74. http:// dx.doi.org/10.1016/0378-8741(95)01254

Bonting SL. Sodium-potassium activated adenosine triphosphate and cation transport. In: Membrane and ion transport. Bittar EE (ed). London, Wiley Interscience, 1970.

Burton GN, Ingold KV. $\beta$-carotene, an unusual type of lipid anti-oxidant. Science 1984; 24: 569-76.

http:/ /dx.doi.org/10.1126/science.671015

Chaterjee A, Prakesh S. The treatise of Indian medicinal plants. India, Publication and Information Directorate (CSIR), 1995, 3, pp 38-40.

Chopra RN, Nayar SL, Chopra IC. Glossary of Indian medicinal plants. India, CSIR, 1992, p 50.

Ecobichon DJ. The basis of toxicology testing. New York, CRC Press, 1997, pp 43-86.

Goto A, Yamada K, Yagi N. Physiological and pharmacology of endogenous digitalis like factors. Pharmacol Rev. 1992; 44: 377-99.

Hjerten S, Pan H. Purification and characterization of two forms of low affinity $\mathrm{Ca}^{2+}$ ATPase from erythrocyte membranes. Biochem Biophys Acta 1983; 728: 281-88. http:/ / dx.doi.org/10.1016/0005-2736(83)90480

Kitada Y, Narimatsu A, Suzuki R. Does the positive ionotropic action of novel cardiotonic agent involve mechanism other than cyclic AMP. J Pharmacol. 1987; 243: $639-45$.

Knekt P, Reunanen A, Jarvinen R, Seppanen R, Heliovaara $\mathrm{M}$, Aroma A. Anti-oxidant vitamin intake and coronary mortality in a longitudinal population study. Am J Epidemiol. 1994; 139: 1180-89.

Kritikar KR, Basu BD, Indian medicinal plants. $2^{\text {nd }}$ ed. Bombay, International Book Distributors, 1981, 3, p 1229.

Lowry OH, Rosebrough NJ, Farr AL. Protein measurements with the Folin phenol reagent. J Biol Chem. 1951; 193: 26568.

Mohur AF, Cooke Y. Simple method of measuring serum level of glutamate oxaloacetic acid and glutamate pyruvate transaminase in routine laboratories. J Clin Path. 1979; 193: 265-68.

Nieland A. Lactic acid dehydrogenase of heart muscle. In: Methods in enzymology. New York, Academic Press, 1955, $1, \mathrm{p} 394$.

Ohinisi T, Suzuki T, Suzuki Y, Ozawa K. Comparative study of plasma membrane $\mathrm{Mg}^{2+} \mathrm{ATPase}$ in normal regenerating and malignant cells. Biochem Biophys Acta 1982; 684: 6774. http:/ / dx.doi.org/10.1016/0005-2736(82)90050

Okhawa H, Onishi N. Assay of lipid peroxidation in animal tissue by thiobarbituric acid reaction. Anal Biochem. 1979; 95: 351. http://dx.doi.org/10.1016/0003-2697(79)90738

Prabhu S, Mallika Jainu K, ShyamalaDevi CS. Cardio protective effect of magnifera on isoproterenol-induced myocardial infarction in rats. Indian J Exper Biol. 2006; 44: 109-25.

Prochezhian E, Ansari SH. Analgesic and anti-inflammatory activity of volatile oil from Daucus carota Linn. Indian J Nat Prod. 2000; 16: 24-26.

Reitman S, Frankel S. A colorimetric method of measuring 
serum level of glutamate oxaloacetate transaminase and glutamate pyruvate transaminase. Am J Clin Path. 1957; 28: 56 .

Rona G, Chappel CJ, Balazs T, Gaudry R. An infarct like myocardial lesion and other toxic manifestations produced by isoproterenol in the rat. Arch Path. 1959; 76: 443-55.

Senthil Kumar H, Anandan R, Santhosh Kumar M.
Cardioprotective effect of Picorrhiza kurrooa against isoproterenol-induced myocardial stress in rats. Fitotherapia 2001; 72: 402. http://dx.doi.org/ 10.1016/ S0367-326X(01)00264

Suchalata S, ShyamalaDevi CS. Protective effect of Terminalia chebula against experimental myocardial injury induced by isoproterenol. Indian J Exper Biol. 2004; 42: 174.

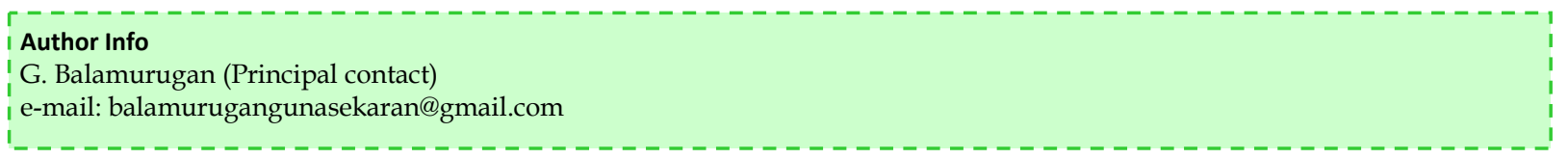

